\title{
Odor-Induced, Activity-Dependent Transneuronal Gene Induction In Vitro: Mediation by NMDA Receptors
}

\author{
A. C. Puche and M. T. Shipley \\ Department of Anatomy and Neurobiology, Program in Neuroscience, School of Medicine, University of Maryland, \\ Baltimore, Maryland 21201
}

\begin{abstract}
Expression of tyrosine hydroxylase $(\mathrm{TH})$ by juxtaglomerular (JG) neurons of the olfactory bulb $(\mathrm{OB})$ requires innervation of the bulb by olfactory receptor neurons (ORNs). ORN lesion selectively downregulates TH in JG neurons. In reversible odor deprivation, TH expression is downregulated as the naris is closed and then upregulated upon naris reopening. The mechanism or mechanisms regulating this dependence are unknown. TH expression could be regulated by trophic factor release and/or synaptic activity from ORN terminals. We investigated TH expression in cocultures of dissociated postnatal rat $O B$ cells and embryonic olfactory neuroepithelium (OE) slice explants. THpositive neurons in control dissociated OB cell cultures alone comprise only a small fraction of the total population of cells present in the culture. However, when OE slice explants are cocultured with dispersed OB cells, there is a mean 2.4-fold increase in the number of $\mathrm{TH}$-positive neurons. ORNs in vivo
\end{abstract}

The factors that regulate development and maintenance of neurotransmitter systems is a central issue in neurobiology. The expression and functions of neurotransmitters change throughout development, aging, and in disease states. For example, the transmitter GABA can be excitatory during development, but is predominantly inhibitory in adults (Chen et al., 1996; Ben-Ari et al., 1997). Parkinson's disease is the result of a selective depletion of the dopaminergic population of neurons in the substantia nigra. Because of the importance of dopamine in the phenotype of Parkinson's disease, an understanding of the regulation of this neurotransmitter is of particularly broad significance.

Tyrosine hydroxylase $(\mathrm{TH})$ is the rate-limiting enzyme in the dopamine biosynthetic pathway (Levitt et al., 1965). TH is abundant in the striatum, substantia nigra, olfactory bulb (OB), and other regions of the brain (Halasz et al., 1977, 1981; Swanson et al., 1982; McLean and Shipley, 1988). In rat, there are 100,000 150,000 dopaminergic neurons in the OB (McLean and Shipley, 1988), compared with $\sim 24,000$ in substantia nigra and ventral tegmental area (Guyenet and Crane, 1981; Swanson et al., 1982). In the $\mathrm{OB}, \mathrm{TH}$ is expressed by juxtaglomerular neurons (periglomerular and external tufted cells) surrounding olfactory glomeruli (Halasz et al., 1977, 1981; Davis and Macrides, 1983). Olfac-

\footnotetext{
Received Aug. 24, 1998; revised Nov. 30, 1998; accepted Dec. 2, 1998.

This work was supported by National Institute of Health Grant NIDCD-00347. We thank Dr. F. Margolis for the OMP antisera used in this study and his valued comments on this manuscript, and Dr. A. Keller for his advice on the dissociation of olfactory bulb neurons.

Correspondence should be addressed to Dr. M. T. Shipley, Department of Anatomy and Neurobiology, Program in Neuroscience, School of Medicine, University of Maryland, 685 West Baltimore Street, Baltimore, MD 21201.

Copyright (C) 1999 Society for Neuroscience $\quad 0270-6474 / 99 / 191359-12 \$ 05.00 / 0$
}

use glutamate as a neurotransmitter. Broad spectrum excitatory amino acid antagonists (kyurenic acid) or selective antagonists of the NMDA receptor (APV) both prevent induction of $\mathrm{TH}$ expression in OE-OB cocultures. Furthermore, pulse application of NMDA stimulates TH expression in OB neurons in the absence of OE. In vitro, OB TH neurons express NMDA receptors, suggesting that NMDA stimulation is acting directly on $\mathrm{TH}$ neurons. Exposure of $\mathrm{OE}$ explants to natural odorants results in upregulation of $\mathrm{TH}$, presumably through increased ORN activity, which could be blocked by APV. These findings indicate that odorant-stimulated glutamate release by ORN terminals regulates TH expression via NMDA receptors on JG dopaminergic neurons.

Key words: dopamine; tyrosine hydroxylase; neurotransmitters; olfactory; activity-dependent; glutamate tory glomeruli are globular tufts of neuropil containing synapses between terminals of the olfactory nerve, juxtaglomerular interneurons, and second order mitral/tufted neurons. TH expression in the $\mathrm{OB}$ in vivo shows a remarkable dependency on olfactory nerve input (Nadi et al., 1981; Baker et al., 1983). Surgical or chemical deafferentation of the bulb results in the selective downregulation of $\mathrm{TH}$ without a concomitant downregulation of L-DOPA-decarboxylase, glutamic acid decarboxylase, or GABA neurotransmitter in the same neuron population (Baker et al., 1983, 1984; Kosaka et al., 1987; Baker, 1990; Stone et al., 1991). The initial nerve transection experiments of Nadi et al. (1981) suggested that some afferent trophic factor released by the olfactory nerve maintained the expression of $\mathrm{TH}$ in juxtaglomerular neurons. However, subsequent studies showed that naris occlusion, which leaves ORNs and the olfactory nerve intact, also downregulates TH expression (Stone et al., 1990; Baker et al., 1993; Cho et al., 1996). Naris occlusion deprives the olfactory epithelium (OE) of odorant stimulation and reduces ORN synaptic activity. The downregulation of $\mathrm{TH}$ after naris occlusion suggested a role for neuronal activity in the regulation of $\mathrm{TH}$, although naris occlusion may have other effects on ORNs that have not yet been detected. For example, the expression of some trophic factors (e.g., brain-derived neurotrophic factor; BDNF) can be regulated by neuronal activity (Du et al., 1994; Z hou et al., 1994).

To directly investigate the role of ORN activity in control of the dopaminergic phenotype in the $\mathrm{OB}$, we developed a coculture model system consisting of dissociated OB neurons grown together with OE organotypic slice explants. Using this model, we tested the hypothesis that ORN activity stimulates synaptic re- 
lease of glutamate from olfactory axon terminals and acts via glutamate receptors on dopaminergic neurons to induce and maintain the expression of TH.

\section{MATERIALS AND METHODS}

Cell culture. Dissociated cultures of OB cells were prepared via modifications of published methods for the dissociation of OB neurons (Trombley and Westbrook, 1990; Carlson et al., 1997). Olfactory bulbs were dissected intact from postnatal day 3 (P3) Sprague Dawley rats. The surrounding dura and arachnoid components of the meninges were removed. To avoid damaging juxtaglomerular neurons, which are located close to the surface of the neonatal bulb, no attempt was made to remove the pia mater encasing the bulb. The bulbs were sliced into $\sim 1 \mathrm{~mm}$ pieces in ice-cold L15 media (Life Technologies, Long Island, NY). These OB pieces were gently agitated in a papain enzyme mix, containing $100 \mathrm{U}$ of cysteine-activated papain (Boehringer Mannheim, Indianapolis, IN), $0.25 \%$ glucose (Sigma, St. Louis, MO), and $1 \mathrm{~mm}$ kyurenic acid (Sigma) in minimal Eagle's media (MEM; Life Technologies), for $20 \mathrm{~min}$ at $22^{\circ} \mathrm{C}$. The OB pieces were sequentially washed in "heavy" inhibitor (two washes each of $4 \mathrm{~min}$ duration), containing $10 \mathrm{mg} / \mathrm{ml}$ egg white trypsin inhibitor (Boehringer Mannheim), $0.25 \%$ glucose, and $1 \mathrm{~mm}$ kyurenic acid in MEM; "light" inhibitor (three washes each of 2 min duration), containing $1 \mathrm{mg} / \mathrm{ml}$ egg white trypsin inhibitor, $0.25 \%$ glucose, and $1 \mathrm{~mm}$ kyurenic acid in MEM; and in trituration medium (one wash of 2 min duration), containing $0.25 \%$ glucose in MEM. These bulb pieces were briefly triturated through a borosilicate glass pipette, and single cells were separated from the residual pieces by filtration through a $70 \mu \mathrm{m}$ cell strainer. Dissociated OB cells were plated onto glass coverslips $(22 \times 22$ $\mathrm{mm})$ at medium-low cell density $\left(\sim 10,000-12,000 \mathrm{cells} / \mathrm{cm}^{2}\right)$ and grown for 5-10 d in Neurobasal (Life Technologies) supplemented with the B27 serum-free additive (Life Technologies) at $37^{\circ} \mathrm{C}$ in $5 \% \mathrm{CO}_{2}$. One half of the culture medium was changed every $2 \mathrm{~d}$ throughout the culture period.

Coverslips were prepared by washing in $100 \%$ ethanol, air drying, and autoclaving. These sterile coverslips were coated with $5 \mu \mathrm{g} / \mathrm{ml}$ of polyL-lysine (molecular weight 70,000-150,000; Sigma) in Gey's balanced salts solution (GBSS; Life Technologies) for $2 \mathrm{hr}$ at $37^{\circ} \mathrm{C}$ in $5 \% \mathrm{CO}_{2}$, washed with GBSS, and coated with $2.5 \mu \mathrm{g} / \mathrm{ml}$ laminin in GBSS at $37^{\circ} \mathrm{C}$ in $5 \% \mathrm{CO}_{2}$ for $2 \mathrm{hr}$.

OE slice explants were prepared as previously described (Gong et al., $1996)$ with the following modifications. Tissue was harvested from embryonic day 14 (E14) Sprague Dawley rat embryos (Zivic-Miller corporation; the day of positive vaginal plug was considered E0). Embryos were removed one at a time, dissected in ice-cold L15 medium (Life Technologies), and $200 \mu \mathrm{m}$ sagittal slices were cut by vibratome sectioning. Small (0.5-1.0 mm length) explants of OE were carefully dissected away from the underlying lamina propria. The resulting OE slice explants were plated onto a coverslip containing a low-density $5 \mathrm{~d}$ in vitro dissociated olfactory bulb neuron culture. Excess medium was removed and the explant allowed to settle and adhere onto the coverslip for $16 \mathrm{hr}$ at $37^{\circ} \mathrm{C}$ in $5 \% \mathrm{CO}_{2}$ before flooding with medium. Initial experiments were performed with between 2 and 10 explants per coverslip, and subsequent experiments were conducted with six OE explants (antagonist experiments) or four explants (agonist experiments). One half of the culture medium was changed every $2 \mathrm{~d}$ throughout the culture period, typically $4 \mathrm{~d}$.

Twenty four hours after explant plating, the cocultures were exposed to one or more of the following conditions: (1) $1 \mathrm{~mm}$ kyurenic acid (Sigma); (2) $100 \mu \mathrm{M}$ 2-amino-5-phosphonopentanoic acid (APV; Sigma); (3) $10 \mu$ M 6,7-dinitroquinoxaline-2,3-dione (DNQX; Calbiochem, San Diego, CA) or $10 \mu \mathrm{M}$ 6-cyano-7-nitroquinoxaline-2,3-dione (CNQX; Calbiochem); (4) $2 \mathrm{mM} \mathrm{CoCl}_{2}$ (Sigma); (5) $2 \mathrm{~mm} \mathrm{MnCl}_{2}$ (Sigma); (6) 0.1-10 $\mu \mathrm{M}$ NMDA (Calbiochem); (7) $0.001 \%$ natural odorant mix of heat-inactivated $\left(15 \mathrm{~min}, 98^{\circ} \mathrm{C}\right)$ aqueous peanut butter (PB; Kraft); (8) $500 \mathrm{nM} \omega$-conotoxin GVIA (Alomone Laboratories); (9) $10 \mu \mathrm{M}$ nifedipine (Alomone Laboratories); (10) vehicle-only treatment. Kyurenic acid, APV, CNQX, and DNQX were all held in the cocultures over 48-72 hr. However, tonic application of the agonist NMDA results in excitotoxic cell death and receptor desensitization. To avoid these problems, NMDA was applied in short 15 min "pulses" followed by intervening washout periods. Under culture conditions, there is a high concentration of glycine $(400 \mu \mathrm{M})$ in the media, which will block rapid NMDA receptor desensitization occurring over a few seconds (Mayer et al., 1989, 1991) and potentiate NMDA currents (Johnson and Ascher, 1987). However, long-term glycine-independent desensitization (Mayer et al., 1991) and excitotoxicity will still occur after $15 \mathrm{~min}$, thereby necessitating pulsatile agonist application. Culture conditions also contain $0.8 \mu \mathrm{M}$ $\mathrm{Mg}^{2+}$ rather than $1.2 \mu \mathrm{M}$ commonly used in electrophysiological recording solutions, thereby resulting in a slightly less stringent $\mathrm{Mg}^{2+}$ block on the NMDA receptor. The application of odorants also suffer from receptor desensitization and adaptation. Therefore, to avoid adaptation to the presence of odorants, PB was also applied in a series of pulses with intervening washout periods. Cultures were exposed to agonists or sham diluent for $15 \mathrm{~min}$ at $37^{\circ} \mathrm{C}$ in $5 \% \mathrm{CO}_{2}$, washed out three times with fresh, prewarmed $\mathrm{CO}_{2}$-equilibrated medium, and allowed to rest for $45 \mathrm{~min}$ at $37^{\circ} \mathrm{C}$ in $5 \% \mathrm{CO}_{2}$. Ten pulse cycles were performed over the first day, and a further ten cycles the following day before fixation. At the end of the pharmacological treatment period, cocultures were washed once with fresh medium and fixed in $4 \%$ paraformaldehyde in PBS for 10 min at $22^{\circ} \mathrm{C}$. Each experimental condition was performed in duplicate (each duplicate experiment constitutes an $n$ of 1 ), and repeated at least three times (cultures prepared form different isolations).

Immunocytochemistry. Tissue was blocked with buffered BSA $(2 \%$ bovine serum albumin and $0.3 \%$ Triton X-100 in $0.1 \mathrm{M}$ Tris-buffered isotonic saline, TBS, $\mathrm{pH}$ 7.4) for $30 \mathrm{~min}$ and then incubated with either monoclonal anti-tyrosine hydroxylase antibodies (1:2500; Incstar, Stillwater, MI), monoclonal anti-bromodeoxyuridine antibodies $(1: 1000$; Dako, Carpinteria, CA), goat anti-OMP (1:5000; courtesy of Dr. F. L. Margolis, University of Maryland), rabbit anti-NMDA-R2a, -R2b, or -R2c antibodies (1:1000; Calbiochem), or monoclonal anti-NMDA-R1 antibodies (1:1000; PharMingen, San Diego, CA) for $2 \mathrm{hr}$ at $22^{\circ} \mathrm{C}$. Sections were washed with TBS as above and incubated for $60 \mathrm{~min}$ in biotinylated donkey anti-mouse (1:400; Jackson Laboratories, West Grove, PA), biotinylated rabbit anti-goat (1:400; Vector Laboratories, Burlingame, CA), or biotinylated donkey anti-rabbit antibodies (1:400; Jackson Laboratories), then washed with TBS, incubated with avidinbiotin-horseradish peroxidase (Elite ABC kit; Vector Laboratories) and reacted with diaminobenzidine $(0.5 \mathrm{mg} / \mathrm{ml})$ and $\mathrm{H}_{2} \mathrm{O}_{2}(1.2 \% \mathrm{v} / \mathrm{v})$ following standard procedures for visualization of horseradish peroxidase. Double immunofluorescence was performed with either a combination of donkey anti-mouse-CY3 (1:200; Jackson Laboratories), biotinylated donkey anti-rabbit (1:200; Jackson Laboratories) and streptavidin-CY2 (2 $\mu \mathrm{g} / \mathrm{ml}$; Jackson), or donkey anti-rabbit CY3 (1:200; Jackson Laboratories) and donkey anti-mouse CY2 (1:200; Jackson Laboratories). In control sections, primary antibodies were replaced by normal serum and showed negligible background reactivity.

Photographs were taken on an Nikon Diaphot microscope (Nikon Instruments, Melville, NY) fitted with phase-contrast optics, a Leitz Orthoplan microscope (Leica, Deerfield, IL) fitted with transmitted light optics, or a FluoView personal confocal microscope (Olympus Instruments). Digital microscopy images were captured using either a MicroLumina digital camera (Leaf Scitex Co., Southboro, MA) or via confocal acquisition. The digital images were brightness- and contrastbalanced, assembled into montages using Adobe Photoshop 3.0 (Adobe Systems, San Jose, CA), and printed on a Fuji Pictrography 3000 printer (Fuji PhotoFilm, Tokyo, Japan). No additional digital image manipulation was performed.

Cell counts and statistical analysis. All tyrosine hydroxylaseimmunoreactive cells, regardless of cell size or labeling intensity, were counted on each coverslip, thereby avoiding any counting bias that could arise from differences in cell size, cell clumping, or uneven cell plating. Quantitative data are presented as a ratio (percentage) of TH-positive cell numbers in the test condition versus density and treatment-matched control plates present in each experiment \pm SE of the difference (no change between test and control numbers thus corresponds to $100 \%$ of control in all figures). Comparisons were always made from the same plating for each experiment (i.e., paired data), which is crucial for primary cell plating (but often not considered), and the paired data were analyzed. The paired $t$ test, which is a parametric test robust in the face of violations in normality, the Wilcoxon signed rank test, the nonparametric equivalent of the paired $t$ test, and ANOVA multiple comparisons (Bonferroni and Tukey-Kramer multiple comparison procedure) were used to analyze differences between experimental manipulation and density-matched control (basic ANOVA comparisons are technically not valid for paired data, however, they were performed as a quick initial check for differences before the use of parametric and nonparametric paired statistics and paired ANOVA multiple comparison procedures as described above). Both parametric and nonparametric statistics resulted in $p$ values of the same order of magnitude, therefore, only the nonparametric $p$ values are presented in Results. 

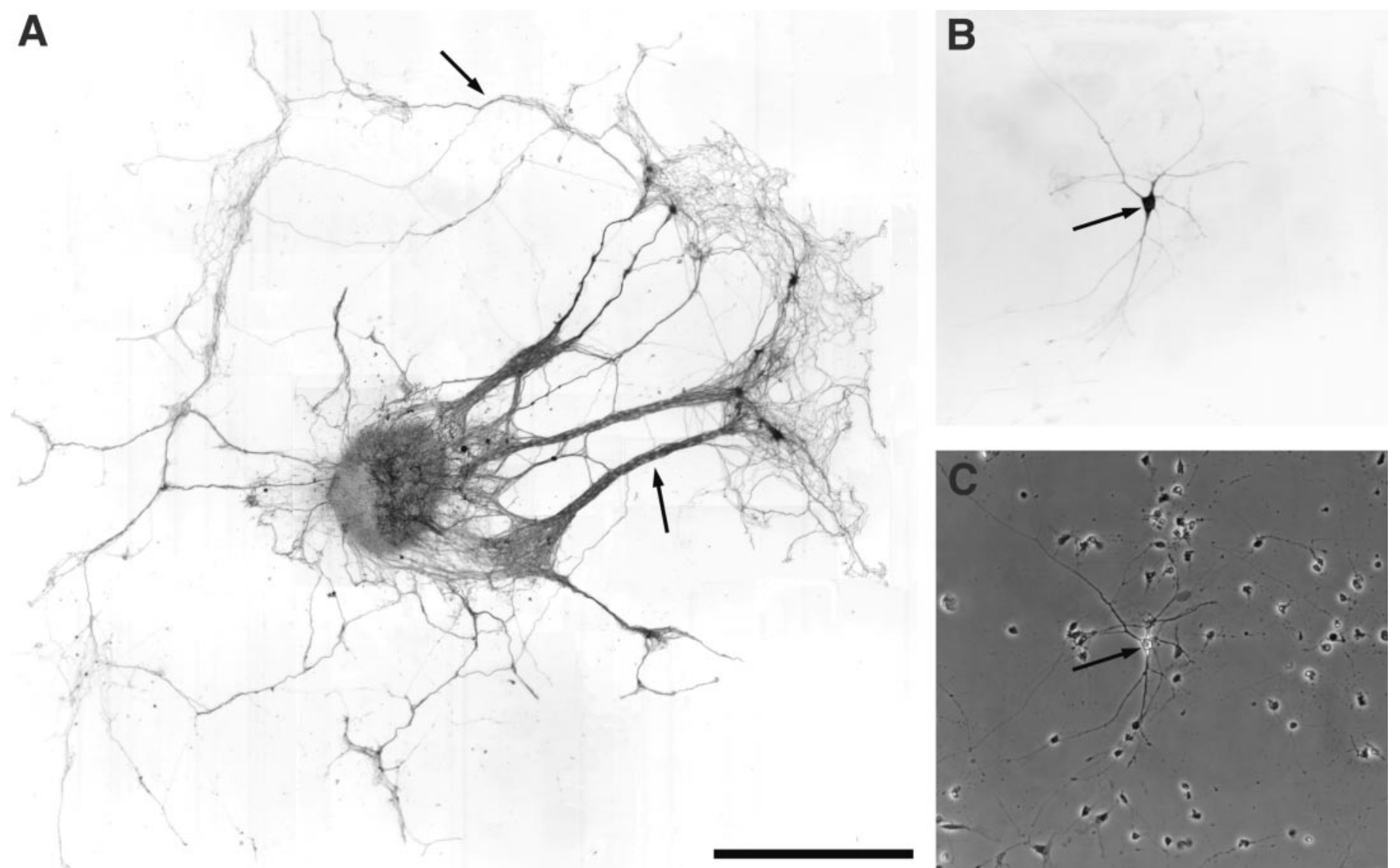

Figure 1. A, An OE explant from E14 rat maintained in vitro for $5 \mathrm{~d}$ extends numerous long axons from the explant onto the substrate. These axon bundles and processes strongly express the olfactory marker protein (arrows). B, A high-power micrograph showing an OB neuron expressing tyrosine hydroxylase after $10 \mathrm{~d}$ in culture (arrow). These neurons form extensive neurite arbors and contact other bulb cells within the culture. $C$, Phase-contrast micrograph of $B$ demonstrating the presence of the TH-expressing neuron (arrow) and other OB neurons not expressing tyrosine hydroxylase. Scale bars: $A, 1 \mathrm{~mm}$ (represents $150 \mu \mathrm{m}$ in $B$ and $C$ ).

\section{RESULTS}

\section{Olfactory neuroepithelial slice explants induce TH expression in olfactory bulb neurons in vitro}

The dopaminergic phenotype in a subpopulation of juxtaglomerular (JG) neurons in the OB is dependent on innervation by the olfactory nerve in vivo (Nadi et al., 1981; Baker et al., 1983). Here, we investigated the mechanisms underlying this dependence using a novel tissue culture model consisting of a coculture of dissociated $\mathrm{OB}$ cells and slice explants of $\mathrm{OE}$. In vivo, JG neuron TH expression is first detectable around E18 in rat (McLean and Shipley, 1988). Previous reports in the literature, and personal experience, indicated that dissociated neuron cultures from animals older than P8 exhibit an age-dependent reduction in longterm cell survival. Therefore, our cocultures used OB cells taken from P2-P5 animals. These dissociated OB cells comprised a mixture of neurons from all layers of the bulb, as well as glia. P2-P5 olfactory bulbs contain fewer glia than more mature bulbs (P8-P14). To further reduce glial cell growth the neuronal medium, Neurobasal/B27, was used. This minimal medium retards glial cell growth and enhances the long-term survival of cortical and hippocampal neurons (Brewer et al., 1993). Thus, at the end of the culture period there are still relatively few glial cells in the cocultures. In $\mathrm{OB}$ cultures, neurons produced extensive neurite arbors and formed numerous contacts with other cells in the culture (Fig. 1; Carlson et al., 1997). Experimental manipulations were only performed on $\mathrm{OB}$ cultures after they had been $5 \mathrm{~d}$ in vitro. This "pre-experimental" culture time was essential to allow cells damaged by dissociation to perish and for surviving cells to form dendrites, axons, and synapses, which does not occur in cortical neuron cultures until 3-4 d in vitro (De Lima et al., 1997), and to recover electrophysiological responses to amino acids. Both IPSPs and EPSPs are observed in OB cultures at $5 \mathrm{~d}$ in vitro (Trombley and Westbrook, 1990; Trombley and Shepherd, 1992), indicating that OB cells at the "age" used in the present experiments are electrophysiologically competent and respond to excitatory amino acid stimulation.

OE slice explants when plated alone (Gong et al., 1996) or with dissociated $\mathrm{OB}$ cells extend numerous long axons (Fig. 1 $\mathrm{A}$ ). These ORN axons extend $\sim 1.5-3 \mathrm{~mm}$ from the slice explant (Fig. $1 A)$. A small population of luteinizing hormone-releasing hormone neurons and glial cells also migrate away from these OE explants (Fueshko and Wray, 1994; Gong et al., 1996; Fueshko et al., 1998). However, TH-positive neurons were never observed in, or migrating from, OE explants under any growth/experimental conditions (data not shown).

In dissociated $\mathrm{OB}$ neuronal cultures alone, a small baseline number of cells $(\sim 20-30)$ expressed tyrosine hydroxylase. However, after coculture with $\mathrm{OE}$ slice explants, the number of $\mathrm{TH}+$ cells increased $\sim 2.5$ fold ( $p<0.00001 ; n=25$; Fig. $2 A$ ). There were also obvious differences in labeling intensity among $\mathrm{TH}+$ 
A
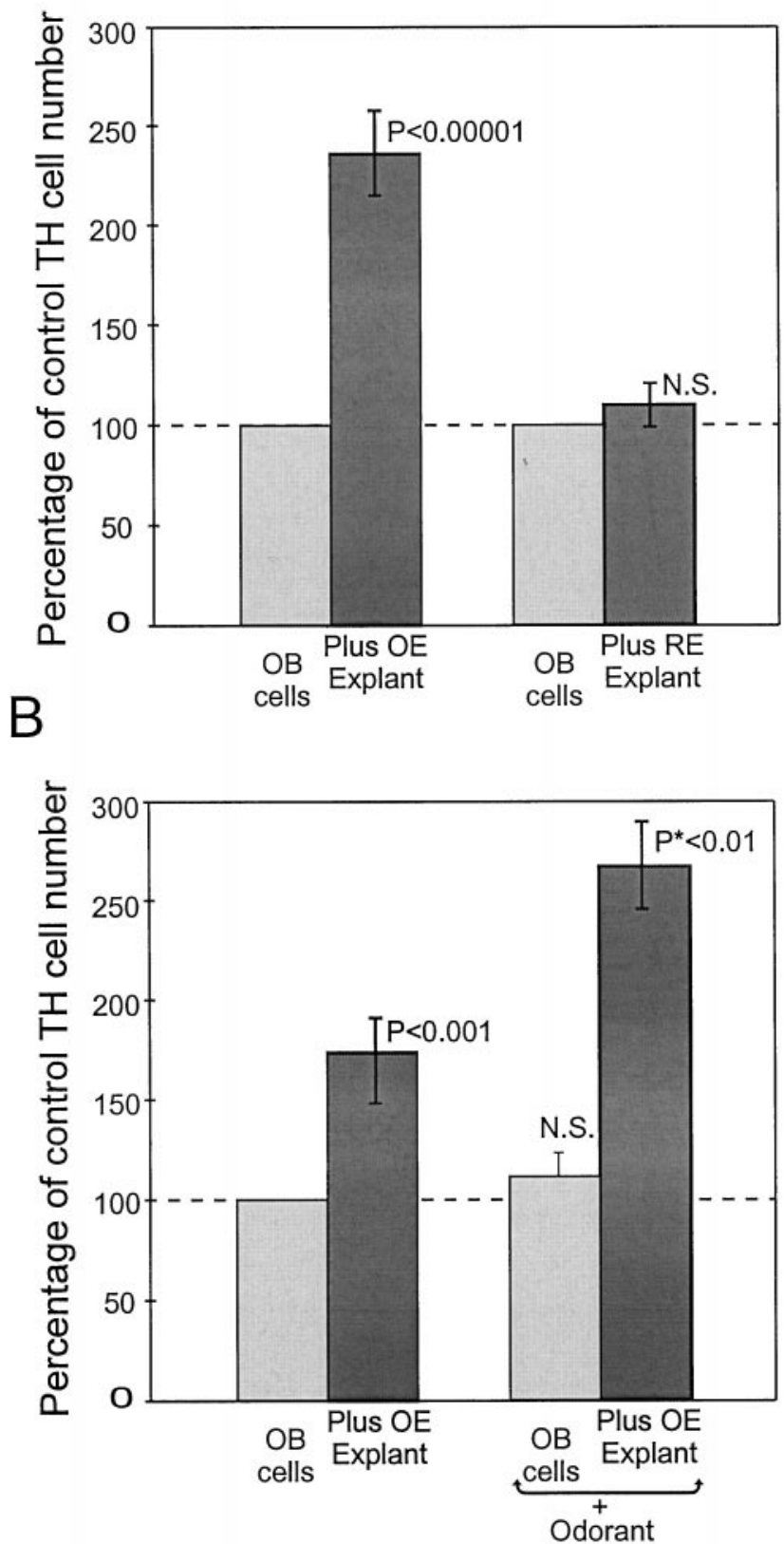

Figure 2. A, Quantification of TH-positive cells in cocultures of dissociated $\mathrm{OB}$ neurons plus $\mathrm{OE}$ explants and dissociated $\mathrm{OB}$ cells plus respiratory epithelium explants. The ordinate shows the percentage of control $\mathrm{TH}$ neuron numbers, and the abscissa shows culture conditions. When olfactory bulb neurons are cultured with olfactory epithelial explants, the number of TH-positive OB neurons rises to $240 \%$ of control numbers. $(p<0.00001$ vs OB cells alone). Cocultures with respiratory epithelium show no significant induction of TH-positive neurons. $B$, Cocultures of OB neurons containing fewer OE explants than $A$ induce $160 \%$ of control TH neuron numbers. This was enhanced to $265 \%$ of control after pulses of odorant $\left({ }^{*} p<0.01\right.$ vs unstimulated $\mathrm{OB}-\mathrm{OE}$ cocultures).

neurons within each culture, which presumably reflect differences in the levels of TH expression. However, no attempt was made to quantify staining intensity in these experiments. When respiratory epithelium (RE) slice explants, which lack ORNs, were cocultured with $\mathrm{OB}$ cells, there was no change in the number of $\mathrm{TH}+$ neurons compared with $\mathrm{OB}$ cultures grown alone (Fig. $2 A$ ).
These observations support a requirement of ORNs for the induction of $\mathrm{TH}$ in $\mathrm{OB}$ target neurons similar to the in vivo observation. In cocultures of dissociated cerebellum cells and OE slice explants, there were never any $\mathrm{TH}+$ cerebellum neurons (data not shown). This shows that the inductive effect of $\mathrm{OE}$ explants in regulating the $\mathrm{TH}$ phenotype is selective for $\mathrm{OB}$ neurons.

Preliminary experiments with different densities of OB cells revealed a density dependence of the number of $\mathrm{TH}$ cells that could be induced by OE coculture. Very low-density cultures ( $<10 \mathrm{TH}$ neurons per coverslip) exhibited 300-400\% increases when cocultured with OE slices, whereas high-density $(>200 \mathrm{TH}$ neurons per coverslip) cultures had a modest $30-50 \%$ increase. Low-density cultures have too few $\mathrm{TH}+$ cells for reliable statistics, therefore all subsequent experiments were performed at a moderate cell density. This resulted in $\sim 20 \mathrm{TH}+$ neurons in $\mathrm{OB}$ cultures alone, which increased to $\sim 50 \mathrm{TH}+$ neurons when cocultured with $\mathrm{OE}$ slices. The inductive effect of $\mathrm{OE}$ could be caused by gene induction in neurons not yet expressing TH or to neurogenesis of new $\mathrm{TH}+$ neurons, or enhanced $\mathrm{OB}$ neuron survival. However, total cell counts in cultures of $\mathrm{OB}$ neurons alone, $\mathrm{OB}-\mathrm{OE}$ cocultures, or RE-OB cultures did not change significantly (data not shown), arguing against a general survival signal. To investigate the possible role of neurogenesis, cultures were exposed to bromodeoxyuridine (BrdU) either at the time OE slices were added, or 24 or $48 \mathrm{hr}$ after OE addition. These cultures had a mean of 4.2 BrdU-labeled cells per 1000 cells $(n=$ 4). Many of these BrdU-labeled cells exhibited the morphological characteristics of glia. The number of BrdU-labeled cells did not change significantly in cocultures containing OE versus RE slice explants or in cultures containing only olfactory bulb cells. Cells within the $\mathrm{OE}$ and RE slice explants were heavily labeled with BrdU. However, these cells were derived from division within the explants and were excluded from BrdU-labeled cell counts. Significantly, in no circumstances did TH-expressing neurons incorporate BrdU. These findings demonstrate that the $\mathrm{TH}+$ neuron population was postmitotic by the time slice explants were added to the culture (5 d after initial OB cell isolation). Thus, the $\mathrm{TH}$-inductive effect of $\mathrm{OE}$ is caused by gene expression in $\mathrm{OB}$ neurons.

\section{Odorant stimulation of ORNs drives TH expression in cocultured OB neurons}

In vivo experiments have demonstrated that blockade of neural activity in ORNs by naris occlusion is sufficient to downregulate $\mathrm{TH}$ in $\mathrm{OB}$. The coculture experiments of this study demonstrated that $\mathrm{OE}$ explants have a significant $\mathrm{TH}$-inductive effect on $\mathrm{OB}$ neurons. Based on these findings, we hypothesized that ORN axons from $\mathrm{OE}$ explants spontaneously released transmitter that acted on $\mathrm{OB}$ neurons to induce $\mathrm{TH}$. If this hypothesis is correct, then stimulation of the OE explants with odor stimuli should increase the TH-inductive effect in $\mathrm{OB}$ neurons in vitro.

Acutely dissociated and long term in vitro preparations of rat ORNs respond to odorant stimulation (Pixley and Pun, 1990; Trombley and Westbrook, 1991; Ronnett et al., 1993). Preliminary evidence from our laboratory using calcium- and voltagesensitive dyes indicate that organotypic slice cultures of $\mathrm{OE}$ also respond vigorously to odorant application. Therefore, we reasoned that it should be possible to selectively stimulate ORNs and thus increase transmitter release by application of short odorant pulses. The aqueous components of PB form a potent natural odorant mixture. Recent data suggests that individual olfactory 


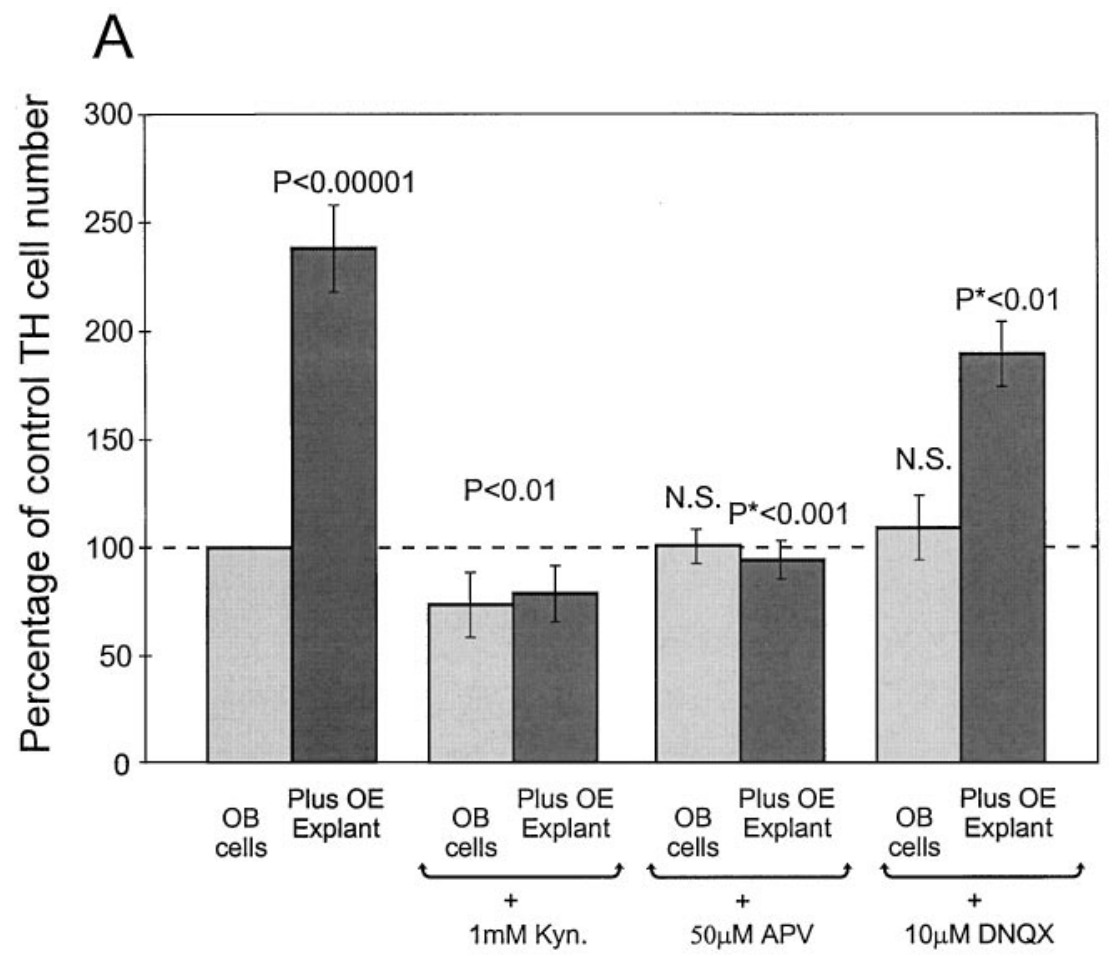

B

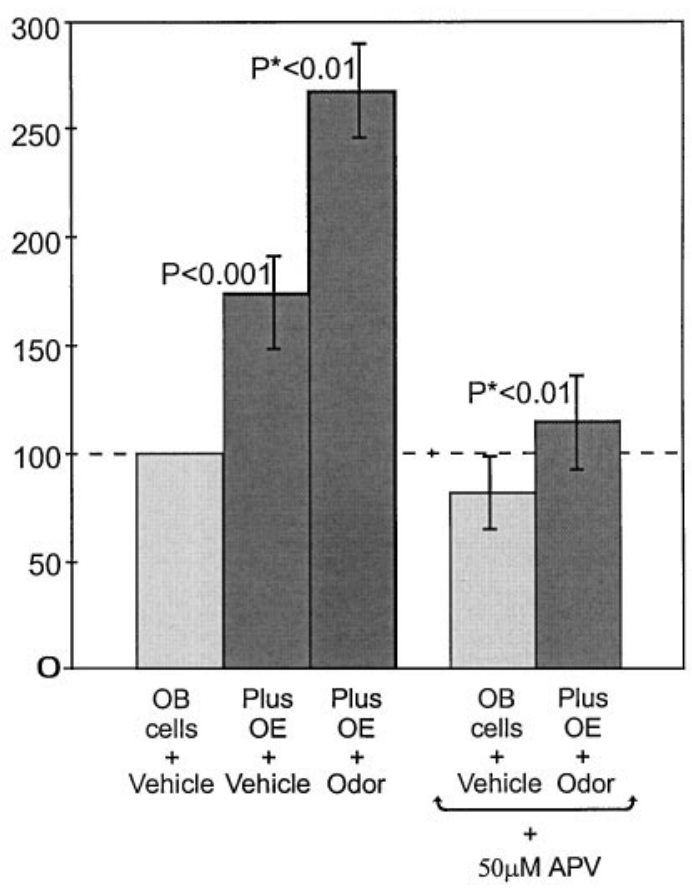

Figure 3. Quantification of TH-positive cells in cocultures of dissociated OB neurons plus OE explants $(A)$ treated with either 1 mM kyurenic acid, 50 $\mu \mathrm{M}$ APV, or $10 \mu \mathrm{M}$ DNQX $(B)$. The addition of either $1 \mathrm{~mm}$ kyurenic acid or $50 \mu \mathrm{M}$ APV prevented the induction of TH neurons in cocultures $\left({ }^{*} p<\right.$ $0.001 \mathrm{vs} \mathrm{OB}-\mathrm{OE}$ coculture) and significantly reduced the basal TH neuron numbers ( $p<0.01$ for kyurenic acid). In the presence of DNQX, TH neurons show a reduced level of induction in cocultures $\left({ }^{*} p<0.01\right.$ vs OB-OE cocultures) without affecting basal levels. $B$, OB neurons alone stimulated with vehicle pulses show baseline TH expression. This expression is enhanced by the addition of OE explants $(p<0.001)$ and further enhanced by odorant stimulation $(p<0.01)$. Odorant stimulation of OB neurons in the absence of OE explants did not significantly affect TH expression (Fig. $2 B)$. The addition of $100 \mu \mathrm{M}$ APV prevented all TH induction by OE explants and odor stimulation $\left({ }^{*} p<0.01\right.$ vs odorant-stimulated OB-OE cocultures).

receptors have a limited response range to odors (Reed, 1998; Zhao et al., 1998). Each odorant receptor gene appeared to respond specifically to only a single chemical molecule or very closely related molecules (Reed, 1998; Zhao et al., 1998). Therefore, even classical 10-odor mixtures might not activate extensive numbers of odorant receptor genes, and thus ORNs, in our cultures. However, the complex odorant mixture found in food substances is usually comprised of many hundreds of different molecules (Maarse, 1991). One of the most common food source stimulants for rodents in behavioral studies is PB. This mixture of odorants is likely to stimulate many more ORNs than a defined 10 -odor mixture commonly used in biophysical studies. Urine is also a common behavioral stimulant, but the toxic aspects of this mixture made it undesirable for cellular experiments. Pulse application of the aqueous components of PB specifically increased the number of $\mathrm{TH}$ neurons in $\mathrm{OE}-\mathrm{OB}$ cocultures versus unstimulated control cultures ( $265 \%$ increase; $p<0.01 ; n=4$; Fig. $2 B$ ). Control cultures of $\mathrm{OB}$ neurons alone had no significant change in TH expression after odorant stimulation. The effects of odor "intensity" and "quality" on neuronal activity and TH expression were not investigated.

\section{Antagonists of the NMDA receptor specifically inhibit TH induction by OE slice explants}

Recent evidence indicates that ORNs release glutamate as their principle neurotransmitter (Ennis et al., 1996). Glutamate acts via AMPA/kainate and NMDA receptors to activate OB neurons, including mitral/tufted cells and JG neurons (Aroniadou-
Anderjaska et al., 1993; Ennis et al., 1996; Keller et al., 1998). The results of the odor-mediated increase in $\mathrm{TH}$ expression above suggested that in vitro, ORNs in the OE explants release glutamate from their axon terminals into the surrounding medium to induce $\mathrm{TH}$ expression. This hypothesis was investigated in the $\mathrm{OE}-\mathrm{OB}$ cocultures with the use of specific glutamate receptor antagonists. The ionotropic glutamate receptors (AMPA/kainate and NMDA receptors) are inhibited by the broad spectrum antagonist kyurenic acid. Addition of $1 \mathrm{~mm}$ kyurenic acid (KYN) directly to the medium in $\mathrm{OE}-\mathrm{OB}$ cocultures prevented the induction of TH $(p<0.01 ; n=3$; Fig. $3 A)$. KYN, added to OB cultures grown alone, without $\mathrm{OE}$ explants, also reduced the basal expression of $\mathrm{TH}$ in $\mathrm{OB}$ cells alone to $75 \%$ of untreated levels $(p<0.05)$, suggesting that the baseline expression of TH by OB neurons cultures alone is caused by spontaneously released glutamate.

NMDA receptor-mediated activity has been implicated in the regulation of gene expression in other regions of the nervous system (Bading et al., 1993; Schulman, 1993; Xia et al., 1996). NMDA receptors are specifically inhibited by the antagonist APV. Therefore, we next investigated the role of NMDA receptors in $\mathrm{TH}$ induction. OE slice explant-dependent induction of $\mathrm{TH}$ in OB neurons was prevented by the addition of $100 \mu \mathrm{M} \mathrm{APV}$ to the culture medium ( $p<0.001 ; n=5$; Fig. $3 A$ ). Thus, induction of $\mathrm{TH}$ requires the excitatory amino acid glutamate and activation of NMDA receptors.

NMDA receptors are normally under $\mathrm{Mg}^{2+}$ block. Activation 


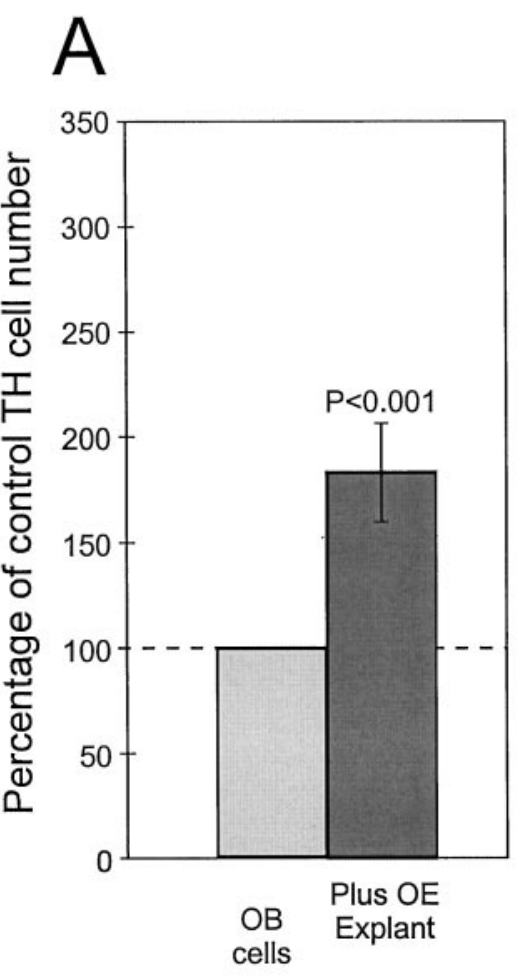

\section{B}

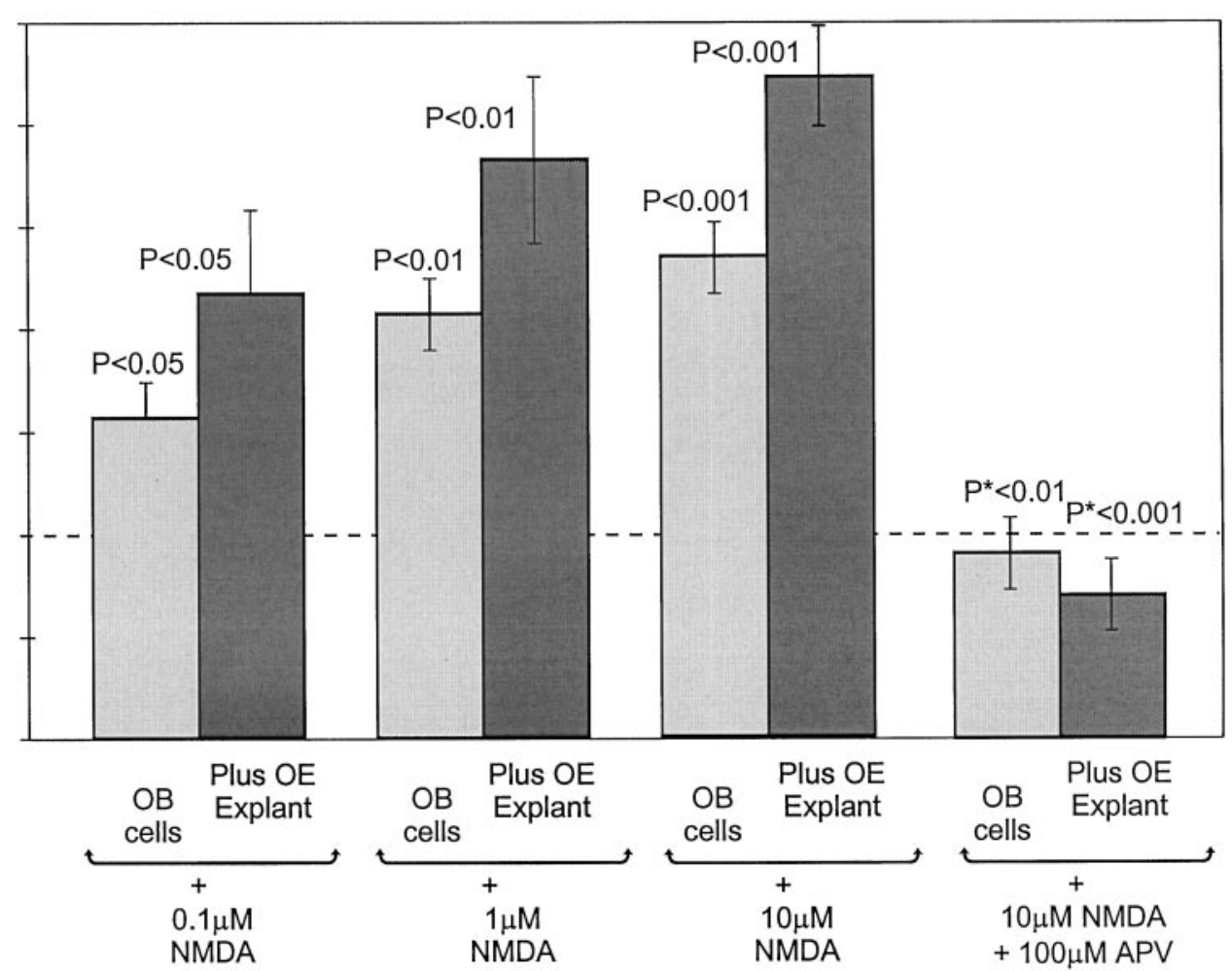

Figure 4. Quantification of TH-positive cells in cocultures of dissociated OB neurons plus OE explants $(A)$ treated with pulses of NMDA $(B)$. Control cultures all received vehicle pulses consisting of culture media. Pulses of NMDA at $0.1 \mu \mathrm{M}$ slightly increased the number of TH-positive OB neurons in both $\mathrm{OB}$ cell cultures and $\mathrm{OB}-\mathrm{OE}$ cocultures $(p<0.05)$. NMDA at 1 and $10 \mu \mathrm{M}$ showed a dose-dependent potentiation of TH neuron expression in $\mathrm{OB}$ cell and OB-OE cocultures ( $p<0.01$ and 0.001 , respectively). The addition of $100 \mu \mathrm{M}$ APV during the treatment period prevented the induction of TH by NMDA stimulation ( ${ }^{*} p<0.001$ compared with $10 \mu \mathrm{M}$ NMDA stimulation).

of AMPA/KA receptors causes a few millivolts of depolarization, which relieves the NMDA receptor of $\mathrm{Mg}^{2+}$ block and allows the influx of $\mathrm{Ca}^{2+}$. Thus, selective antagonism of AMPA/KA receptors should attenuate $\mathrm{TH}$ induction in the OE-OB coculture. The antagonist DNQX is a specific AMPA/ kainate receptor blocker. Addition of DNQX $(10 \mu \mathrm{M})$ to the culture medium partially inhibited TH induction by $\mathrm{OE}$ explants $(p<0.01 ; n=4$; Fig. $3 A)$.

As shown above, exposure of OE-OB explants to odorant stimulation significantly increased the induction of TH. Therefore, we next investigated whether antagonism of NMDA receptors blocked the inductive effect of odor stimulation. APV, added to cultures before the application of odor stimulation, completely prevented the induction of TH $(p<0.001 ; n=3$; Fig. $3 B)$, This result demonstrates that glutamate signaling is necessary for in vitro odorant-stimulated $\mathrm{TH}$ induction.

There were no differences in cell attachment or survival in any of these pharmacological antagonist treatments (data not shown).

\section{NMDA directly stimulates expression of TH in olfactory bulb neurons}

The blockade of TH induction by the NMDA receptor antagonists APV and kyurenic acid in the OB-OE cocultures strongly suggested a role for this receptor in the induction and maintenance of the dopaminergic phenotype in vitro. This hypothesis predicts that agonists of the NMDA receptor should induce $\mathrm{TH}$ expression in the absence of OE explants and potentiate expression in the presence of OE explants. The NMDA receptor is subject to activation, followed by rapid desensitization in the presence of chemical agonists (Lin and Stevens, 1994). Thus, the addition of constant levels of NMDA to the culture medium is likely to desensitize the NMDA receptor and inhibit its function, an inference that was confirmed in the present experiments (data not shown). Pulse application of this agonist minimizes receptor desensitization. Therefore, short pulses of NMDA were applied to either OE-OB cocultures or $\mathrm{OB}$ cultures, alone, over the course of $40 \mathrm{hr}$. Repeated pulse applications of NMDA-induced expression of TH in dissociated $\mathrm{OB}$ neurons cultured alone $(p<$ $0.001 ; n=6$; Fig. 4). The number of TH-positive cells induced by pulses of NMDA in the absence of OE was dose-dependent, 56\% increase above sham pulse controls at $0.1 \mu \mathrm{M}$ NMDA $(p<0.05)$, $103 \%$ increase at $1 \mu \mathrm{M}$ NMDA $(p<0.01)$, and $135 \%$ at $10 \mu \mathrm{M}$ NMDA $(p<0.001)$. NMDA pulses applied to OE-OB cocultures potentiated the inductive effects caused by $\mathrm{OE}$ explants alone (187\% induction with OE alone; $225 \%$ induction with OE plus $0.1 \mu \mathrm{M}$ NMDA pulses, $p<0.05 ; 290 \%$ with OE plus $1 \mu \mathrm{M}$ NMDA pulses, $p<0.01$; and $325 \%$ with OE plus $10 \mu \mathrm{M}$ NMDA pulses, $p<0.001$; Fig. 4). NMDA-mediated induction of TH under all conditions was completely blocked by $100 \mu \mathrm{M} \mathrm{APV}$, 


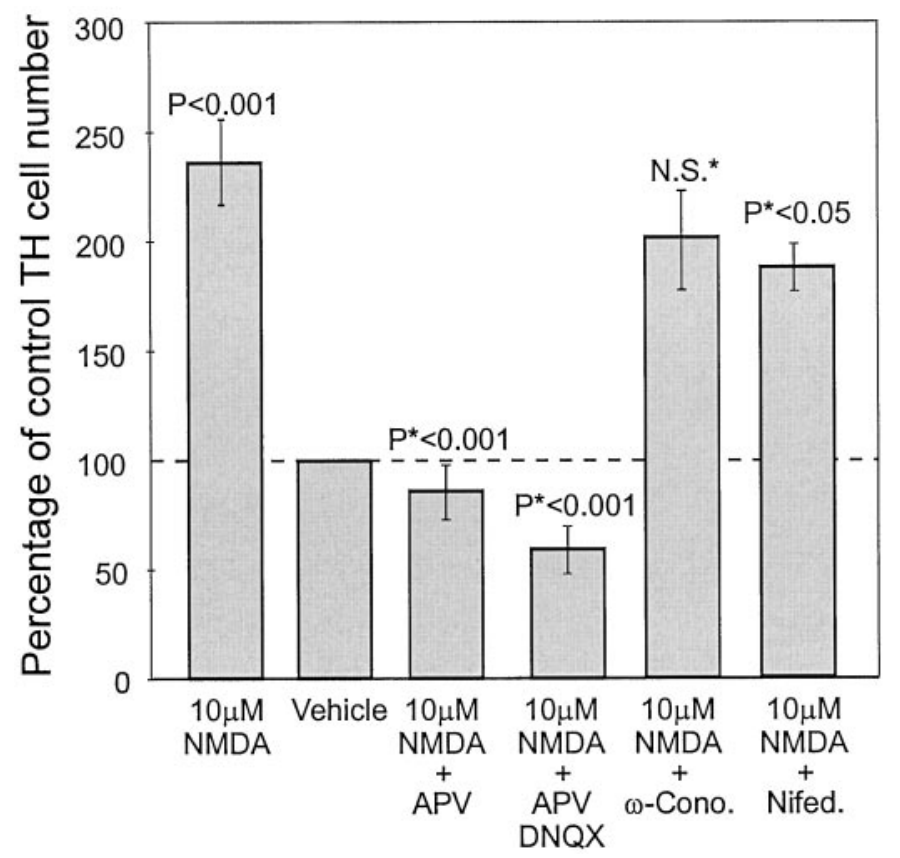

Figure 5. Quantification of TH-positive cells in cultures of NMDAstimulated dissociated OB neurons treated with $100 \mu \mathrm{M}$ APV, $100 \mu \mathrm{M}$ APV and $10 \mu \mathrm{M}$ DNQX, $500 \mathrm{~nm} \omega$-conotoxin GVIA, or $10 \mu \mathrm{M}$ nifedipine. Control cultures all received sham pulses consisting of culture media. Pulses of NMDA at $10 \mu \mathrm{M}$ increased the number of TH-positive OB neurons $(p<0.001)$, which were inhibited by APV $\left({ }^{*} p<0.001\right.$ vs NMDA-stimulated cultures), and APV-DNQX mixtures ( ${ }^{*} p<0.0001$ vs NMDA-stimulated cultures). $\omega$-Conotoxin did not significantly affect TH expression after NMDA stimulation; however, nifedipine reduced NMDA induction of TH from $143 \%$ increase to only $93 \%$ increase $(35 \%$ decrease; ${ }^{*} p<0.05$ vs NMDA-stimulated cultures).

showing that $\mathrm{TH}$ induction was the result of NMDA receptor activation.

\section{Role of non-NMDA-mediated $\mathrm{Ca}^{2+}$ influx}

High concentrations of $\mathrm{KCl}$ depolarize cultured neurons and induce the expression of TH in vagal neurons (Brosenitsch et al., 1998) and olfactory bulb neurons (McMillian et al., 1994; Cigola et al., 1998). This KCl-TH induction is inhibited by the L-type calcium channel blocker nifedipine $(10 \mu \mathrm{M})$, suggesting a role for $\mathrm{Ca}^{2+}$ in TH gene expression (McMillian et al., 1994; Cigola et al., 1998). The present results show that natural stimulation with odors results in the activation of NMDA receptors leading to $\mathrm{Ca}^{2+}$ influx is sufficient to induce TH. However, it is possible that subsequent to NMDA receptor activation, other calcium channels, including voltage-gated channels, contribute to the rise in intracellular calcium. To investigate this, OB neurons cultured alone were pulse-stimulated with NMDA in the presence of NMDA receptor antagonists (100 $\mu \mathrm{M} \mathrm{APV})$, ionotrophic glutamate antagonists (100 $\mu \mathrm{M}$ APV and $10 \mu \mathrm{M}$ DNQX mixture), $\mathrm{N}$-type calcium channel antagonists (500 nм $\omega$-conotoxin GVIA), or L-type calcium channel antagonists (10 $\mu \mathrm{M}$ nifedipine). As seen previously (Fig. 4), the inductive effects of NMDA pulses were prevented by APV and APV-DNQX $(n=6$; Fig. 5). The combination of APV and DNQX was slightly more effective than APV alone and reduced baseline expression to $60 \%$ of control $(p<0.05$; Fig. 5). Blockade of N-type calcium channels did not significantly reduce TH stimulation caused by NMDA $(n=2$; Fig. $5)$. The L-type calcium channel blocker nifedipine caused an

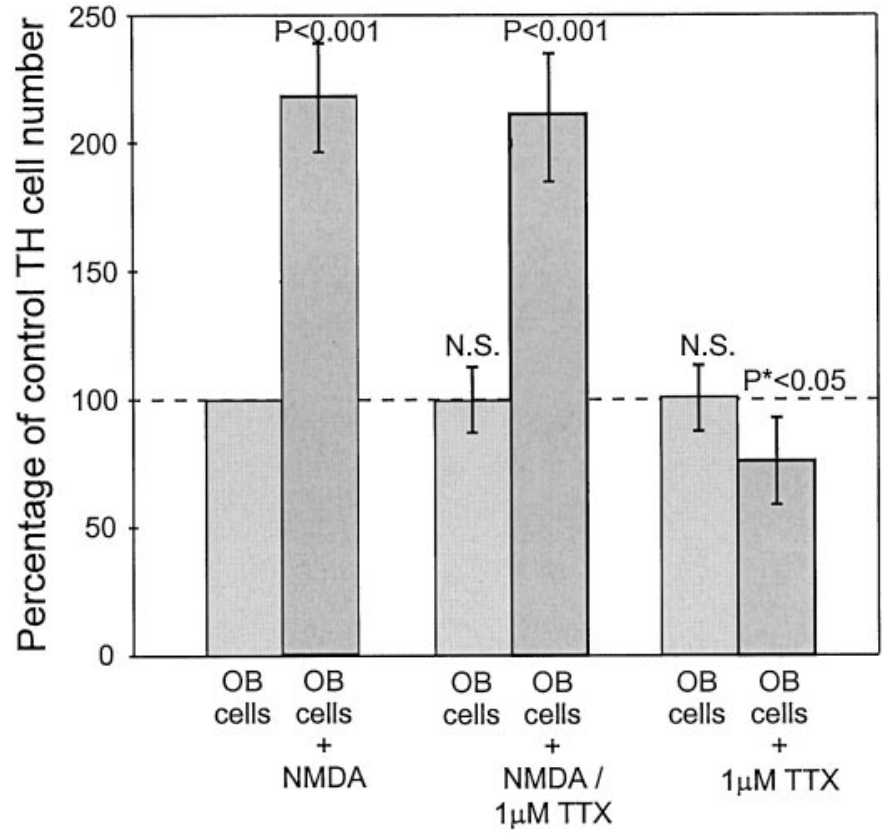

Figure 6. Quantification of TH-positive cells in cultures of dissociated $\mathrm{OB}$ neurons alone. Pulses of NMDA increased the number of TH neuron in cultures of dissociated OB cells by $230 \%(p<0.001)$. This induction was not affected by $1 \mu \mathrm{M}$ TTX, suggesting that the direct effect of NMDA application does not require synaptic transmission. The addition of TTX in sham pulse controls slightly reduced the basal generation of $\mathrm{TH}$ neurons $(p<0.05)$, suggesting this level may in part be caused by spontaneous activity within the cultured OB neurons.

$\sim 30 \%$ reduction of NMDA-mediated induction of $\mathrm{TH}(n=3$; $p<0.05$; Fig. 5). This suggests that when NMDA receptors are activated, most $\mathrm{TH}$ expression depends on calcium influx that occurs through the NMDA receptor, with a potential additional contribution from the L-type calcium channel.

\section{Is NMDA-mediated TH induction caused by direct or indirect effects on TH neurons?}

Our dissociated OB cultures contain a mixture of several classes of $\mathrm{OB}$ neurons and glia. It is possible that $\mathrm{TH}$ induction is secondary to activation of other cell types by NMDA. Two lines of experimental evidence suggest that NMDA acts directly on the dopaminergic neurons and not indirectly via other cell types.

First, induction of TH expression in dissociated OB cells exposed to pulses of NMDA is unaffected by the presence of $1 \mu \mathrm{M}$ tetrodotoxin (TTX; $n=3$; Fig. 6). TTX blocks sodium currents and inhibits synaptic transmission between most neurons in the cultures. Interestingly, $1 \mu \mathrm{M}$ TTX alone reduced the background number of TH-positive neurons by $25 \%$ (Fig. 6). This suggests that at least some of the background $\mathrm{TH}$ expression in dissociated OB cultures is caused by spontaneous synaptic glutamate release.

Second, immunohistochemical staining showed that many dissociated $\mathrm{OB}$ neurons express the both the R1 and R2B NMDA receptor subunits (Fig. 7A-D) and weakly express the R2A subunit (data not shown). These NMDA receptor subunits were localized exclusively to neurons and were not expressed by the glial cells present within the cultures. Significantly, all $\mathrm{TH}+$ neurons in the cultures express both of these NMDA receptor subunits (Fig. $7 C, D$ ). Thus, $\mathrm{TH}+$ neurons have NMDA receptors. Taken together these two results, the direct expression of NMDA receptor components by $\mathrm{TH}$-positive neurons in vitro and 


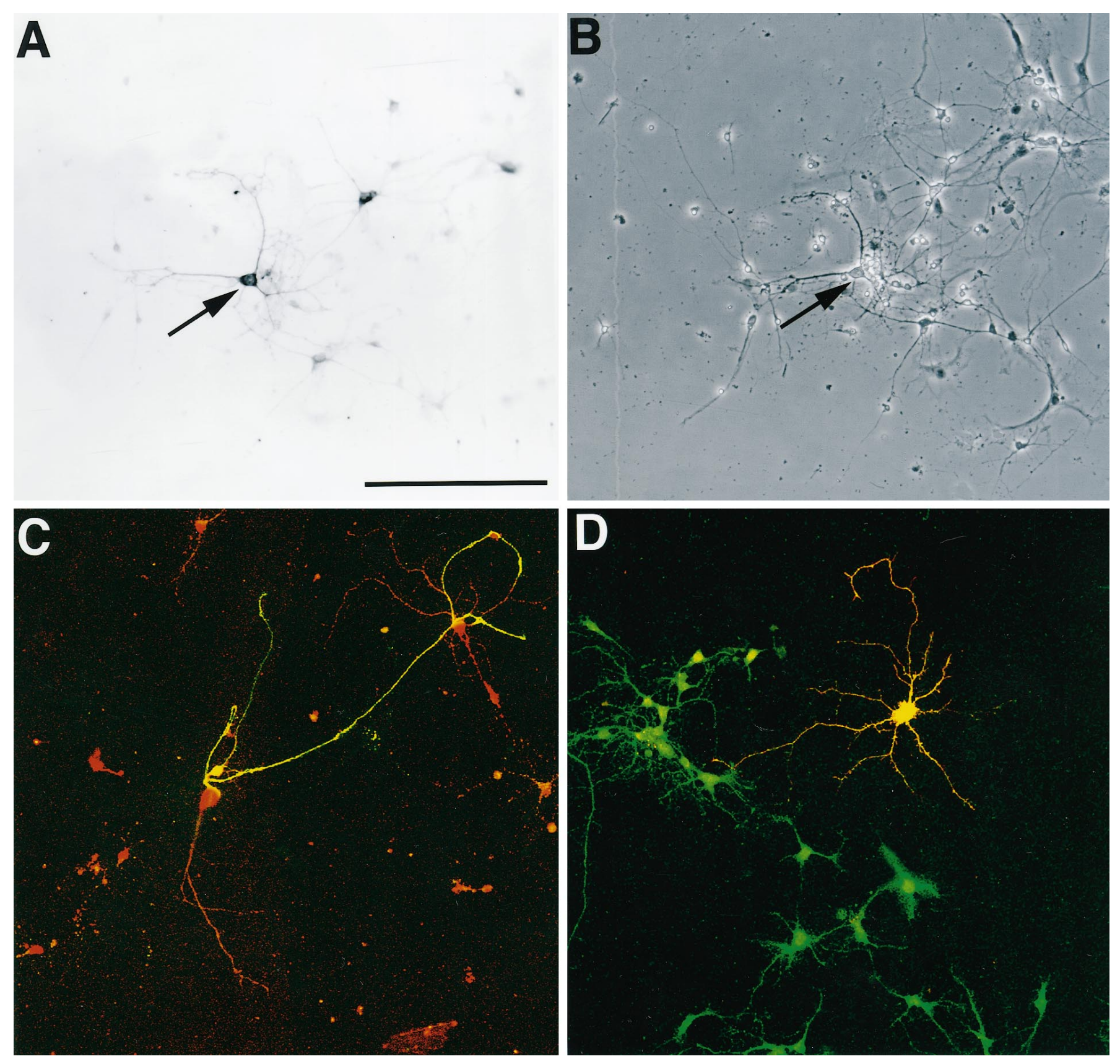

Figure 7. Expression of NMDA receptor subunits $\mathrm{R} 1$ and $\mathrm{R} 2 \mathrm{~B}$ in cultures of dissociated $\mathrm{OB}$ cells. $A$, NMDA receptor subunit $\mathrm{R} 1$ is expressed by many cells within the OB culture (arrow). These cells extend numerous fine processes and are often in contact with other cells in the culture. $B$, Phase contrast demonstrates that there are other cells within the cultures that do not express the NMDAR1 subunit. Some of these cells have the flattened appearance typical of glial cells in culture. $C$, Double immunofluorescence for NMDA receptor subunit R1 (red) and TH (green) shows that the neuron expressing $\mathrm{TH}$ also expresses this NMDA receptor subunit (yellow). D, Immunofluorescence for the NMDA receptor subunit R2A (green) and TH (red) demonstrates that the TH neurons in vitro also coexpress the R2A subunit. TH is distributed evenly throughout the neuron; however, the NMDA receptor subunit is localized to punctate deposits along the cell processes and over the cell perikarya. Processes from TH neurons often contain intense punctate deposits of NMDA receptor at process terminals. Scale bar: $A, 120 \mu \mathrm{m}$ (applies to $A-D$ ).

the inability of TTX to block NMDA-stimulated TH induction, provide evidence for a direct effect of NMDA on DA neuron phenotype in vitro.

\section{DISCUSSION}

The present study shows that $\mathrm{TH}$ expression in cultured $\mathrm{OB}$ neurons is directly regulated by ORN activity-dependent mech- anisms. Cocultures of dissociated OB neurons with OE explants significantly increased the number of bulb neurons expressing TH. The inductive effect of OE explants is prevented by NMDA receptor antagonists and potentiated by NMDA receptor agonists. Moreover, presentation of a "natural" odorant stimulus to cultures containing $\mathrm{OE}$ explants significantly increased $\mathrm{TH}$ expression in the bulb neurons, and this odorant-mediated induction requires activation of the NMDA receptor. This is the first in 
vitro demonstration that a natural sensory stimulant to olfactory neurons can influence gene regulation in postsynaptic target neurons. Taken together, the results of the present study indicate that glutamate release by ORNs, acting on an NMDA receptor, is a key determinant for $\mathrm{TH}$ regulation in vitro.

\section{Tyrosine hydroxylase expression in vitro}

The regulation of $\mathrm{TH}$ in juxtaglomerular neurons of the OB was initially suggested to be the result of either trophic factor release by the ORN terminals or by ORN synaptic activity (Nadi et al., 1981). Later reports suggested that the calcitonin gene-related peptide (CGRP) could induce TH expression in OB neurons in vitro (Denis-Donini, 1989). However, when CGRP innervation to the $\mathrm{OB}$ was eliminated in vivo by neonatal capsaicin treatment or electrolytic lesion of the ophthalmic division of the trigeminal nerve, there was no downregulation of TH in the OB (Finger and Bottger, 1992). These lesions selectively eliminated CGRP innervation but did not affect olfactory receptor neuron projections into the bulb. Furthermore, when ORN input was lesioned by $\mathrm{ZnSO}_{4}$, the CGRP-positive fibers were unaffected, but TH expression was eliminated (Biffo et al., 1990). These experiments demonstrated that CGRP is not an essential factor for TH expression in vivo. It is possible that in vitro exogenous CGRP stimulates non-TH neurons which, in turn, release soluble factors that stimulate the dopaminergic neurons and induce TH expression. In this regard, it would be interesting to determine whether NMDA antagonists block the in vitro inductive effect of CGRP.

Our results indicate that the TH phenotype is dependent on glutamate release by ORNs, acting on NMDA receptors present on the dopaminergic (DA) neurons in vitro. We have three lines of evidence to suggest that the induction of $\mathrm{TH}$ occurs in a predetermined population of neurons in vitro and does not involve mitotic production of new neurons. First, double labeling with BrdU and TH indicated that no TH cells are labeled by BrdU in either cocultures or controls. Thus $\mathrm{TH}+$ cells were not born in response to stimulation. Second, the induction of TH was inhibited by the presence of APV or kyurenic acid, which have not been reported to influence cellular mitosis in olfactory neuron cultures. Third, respiratory epithelium explants, which contain similar non-neuronal elements to the OE explant, did not induce $\mathrm{TH}+$ cells. Collectively, these data rule out the influence of general changes in mitosis as the mechanism for increased $\mathrm{TH}$ cell number in these experiments.

The total number of cells present in heterogeneous OB cultures did not differ significantly between experimental or control groups, indicating that generalized cell survival was not responsible for increased numbers of TH neurons. However, the issue of whether OE-NMDA can selectively enhance the survival of only the TH neuron population is more difficult. A selective enhancement of survival in such a small population in the heterogeneous population of cells in an OB culture would not be detected by total cell counts. Unfortunately, there is no marker for a $\mathrm{TH}$ neuron before its expression of TH that could be used to track the total $\mathrm{TH}$ population independently of $\mathrm{TH}$ expression. Interestingly, most papers dealing with phenotype induction (Cigola et al., 1998) also do not answer this question. This scenario is unlikely but remains a formal possibility.

In the present cultures, the absolute numbers of DA neurons prepared by dissociation of $\mathrm{OB}$ tissue is low $(\sim 50 \mathrm{TH}-$ immunoreactive neurons per coverslip). However, at P2 there are only 800-2400 TH-immunoreactive cells in the OB (McLean and Shipley, 1988), whereas the entire bulb contains $\sim 14.4 \times 10^{5}$ neurons (Frazier and Brunjes, 1988). Therefore, at P2 the TH+ neurons comprise only $0.1 \%$ of the total $\mathrm{OB}$ neuron population, as compared with $2-5 \% \mathrm{TH}$ neurons in mesencephalic primary cultures (Isaacs et al., 1996). The use of older animals, which have more TH+ neurons in the OB (McLean and Shipley, 1988), might be thought to yield a higher percentage of $\mathrm{TH}$-reactive neurons. However, whereas the absolute number of $\mathrm{TH}$ cells per bulb increases with age, there is also rapid expansion of the granule cell population, thus the proportion of $\mathrm{TH}$-immunoreactive neurons present in the bulb does not alter significantly until after 3 weeks postnatal $(0.1 \% \mathrm{TH}$ neurons at $\mathrm{P} 2,0.11 \%$ at $\mathrm{P} 8 ; 0.19 \%$ at $\mathrm{P} 15$; and $0.41 \%$ at $\mathrm{P} 22$ ). The ease of preparation and the excellent survival of early postnatal tissue was optimal for these experiments, in contrast to P22 tissue, in which there is a slightly higher percentage of $\mathrm{TH}+$ neurons but lower long-term in vitro neuronal survival.

The most parsimonious explanation for the effect of the NMDA receptor on $\mathrm{TH}$ expression that we observe is the direct influence on gene expression in the stimulated cell. However, it is theoretically possible that NMDA receptor stimulation results in the release of some other factor that could act autocrine or paracrine manner on dopaminergic neurons to induce TH. For example, the fibroblast growth factor-1 (FGF-1), also known as the acidic fibroblast growth factor (aFGF), and BDNF both upregulate embryonic striatal neuron $\mathrm{TH}$ expression in vitro (Du et al., 1994, 1995; Zhou et al., 1994). Preliminary experiments exposing olfactory neuron cultures to exogenous BDNF did not induce TH expression (our unpublished observations). FGF-1 and BDNF in embryonic striatal cultures might influence differentiation and maturation of the dopaminergic neuron population rather than affecting gene regulation in a pre-existing population of neurons.

\section{Juxtaglomerular neurons and the action of the NMDA receptor}

Juxtaglomerular neurons respond in vivo to electrical stimulation of the olfactory nerve or odor stimulation of ORNs, with a short-latency train of action potentials, rapid run-down in the spike-generating mechanisms, and a long-lasting depolarization before returning to baseline (Wellis and Scott, 1990). Because glutamate is the primary ORN neurotransmitter (Ennis et al., 1996), it is reasonable to suggest that the response of juxtaglomerular neurons is caused by ionotropic glutamate receptor activation. The AMPA-kainate ionotropic glutamate receptor is rapidly activated and inactivated after glutamate binding, whereas the NMDA receptor can contribute to events lasting hundreds of milliseconds (for review, see Conn and Pin, 1997) (Pin and Duvoisin, 1995). Recently, investigation of optical signals from voltage-sensitive dyes shows that juxtaglomerular neurons do indeed respond to olfactory nerve input via both AMPA-KA and NMDA receptors (Keller et al., 1998). The NMDA receptor-mediated responses have the same time course as the long-lasting depolarization seen in earlier electrophysiology studies. Expression of both the R1 and R2b NMDA receptor subunits by olfactory bulb dopaminergic neurons and the induction of $\mathrm{TH}$ in the presence of the $\mathrm{Na}^{+}$current antagonist tetrodotoxin in the present in vitro experiments further argues for the presence of functional NMDA receptors on these neurons and for a direct action of ORN synaptic release of glutamate on $\mathrm{TH}+$ neurons in vivo and in vitro.

During action potentials and long depolarization of juxtaglomerular neurons triggered by glutamate receptor activation, other 
$\mathrm{Ca}^{2+}$ channels, primarily the $\mathrm{N}$ - and L-type, may also be activated. The N-type calcium channels are opened during depolarization but inactivate rapidly. Activation of L-type calcium channels requires strong depolarization, but these channels have a slow decay rate and exhibit continual reopening at the level of single-channel kinetics (Hille, 1992). Therefore, under depolarizing conditions, L-type calcium channels could contribute to increased intracellular $\mathrm{Ca}^{2+}$ and $\mathrm{TH}$ expression. In fact, under strong depolarizing conditions, $50 \mathrm{~mm} \mathrm{KCl}$, TH expression is enhanced in both vagal (Brosenitsch et al., 1998) and OB neurons (McMillian et al., 1994; Cigola et al., 1998); this effect is blocked by antagonists of the L-type channel (Cigola et al., 1998). In the present study, direct NMDA stimulation of OB neurons alone increased TH expression. This TH induction in $\mathrm{OB}$ neurons by NMDA was only partially $(\sim 30 \%)$ attenuated by L-type calcium channel antagonists. However, even the pulsatile applications of NMDA in our experiments probably cause a longer-lasting, more depolarized response than when glutamate is synaptically released by ORN terminals. Thus, our applications of NMDA likely activate more L-type $\mathrm{Ca}^{2+}$ channels and for longer periods than does synaptic activity. Therefore, the significance of this potential contribution of L-type $\mathrm{Ca}^{2+}$ is difficult to interpret. The action of calcium channel antagonists on $\mathrm{TH}$ expression induced by $\mathrm{OE}$ explants was not investigated because of potential ambiguity in interpretation. Calcium channels play an important role in synaptic vesicle release (Wu and Saggau, 1997), therefore $\mathrm{Ca}^{2+}$ antagonists actions could reduce glutamate release from olfactory axon terminals and/or block $\mathrm{Ca}^{2+}$ channels on $\mathrm{OB}$ neurons to reduce $\mathrm{Ca}^{2+}$ influx. This potential contribution of $\mathrm{Ca}^{2+}$ channels, notwithstanding, our findings demonstrate that in $\mathrm{OB}$ neurons a major source of calcium influx resulting in $\mathrm{TH}$ gene expression is through the NMDA receptor.

Gene regulation via NMDA receptor activation has been well characterized in hippocampal neurons (Bading et al., 1993; Xia et al., 1996) and the PC12 neuronal cell line (Schulman, 1993). Some of the same transcription factors and promoter elements activated by glutamate stimulation in these systems are also present in the regulatory elements of the $\mathrm{TH}$ gene. Glutamate stimulation in vitro can activate $\mathrm{Ca}^{2+} /$ calmodulin-dependent kinases (CaM kinases; Schulman, 1993), which are expressed in the olfactory bulb at high levels both during development and in adult (Sakagami and Kondo, 1993; Sawamura et al., 1996) Indeed, the olfactory bulb, hippocampus, and cerebellum retained high levels of expression in adult (Sawamura et al., 1996). CaM kinases in turn can activate the serum response factor (SRF; Miranti et al., 1995) and the cAMP response element-binding protein (CREB; Hardingham et al., 1997) transcriptional factors. The SRF and CREB transcription factors bind to the serum response element (SRE) and the cAMP response element (CRE) promoters, respectively. The regulatory elements of the $\mathrm{TH}$ gene contain a CRE promoter (Kim et al., 1993; Lazaroff et al., 1995) and an activator protein-1 promoter site (AP-1; Yoon and Chikaraishi, 1992). In PC12 cells, transcription of the TH gene involves interactions between CREB at the CRE promoter acting in synergy with fos protein at the AP-1 site (Nagamoto-Combs et al., 1997). Interestingly, $c$-fos induced in dopaminergic neurons of the olfactory bulb after odor stimulation (Guthrie and Gall, 1991). The common transcription elements present in the TH gene promoter region and those known to be activated by glutamate stimulation present a putative direct link from NMDA receptor activation to the genome via CaM kinases, $c$-fos and CREB. Although it is still unclear exactly which transcriptional elements are important for regulation of $\mathrm{TH}$ in $\mathrm{OB}$ neurons, calcium influx and calcium responsive promoter elements are likely to be a critical part of the cascade leading from neuronal activity to gene expression.

\section{A role for an inducible tyrosine hydroxylase enzyme}

The biological role of dopamine in olfactory signal processing is unclear. The DA D2 receptor, but not the D1 receptor, is abundantly localized throughout the olfactory nerve layer and glomerular layer (Nickell et al., 1991; Coronas et al., 1997). Lesions of the olfactory nerve eliminate D2 receptor ligand binding in the theses layer. Olfactory receptor neurons express D2 receptor mRNA (Koster et al., 1998). In OB slice preparations, DA and selective D2 agonists block responses of olfactory bulb neurons to olfactory nerve stimulation (V. Aroniadou-Anderjaska and M. Shipley, unpublished observations). Taken together, these findings suggest that D2 receptors function as presynaptic receptors on olfactory nerve terminals. We conjecture that DA functions to negatively regulate the release of transmitter from olfactory nerve terminals and thus participate in controlling the sensitivity in the OB to odorant stimuli. Low levels of ORN activity, such as in a naris occlusion model (Brunjes et al., 1985), reduce the level of glutamate release on juxtaglomerular neurons and reduce the expression of $\mathrm{TH}$, thus reducing the levels of DA in juxtaglomerular neurons. According to our hypothesis, this would reduce presynaptic inhibition of olfactory nerve terminals. As a consequence, lower levels of neural neuronal activity in ORNs would then have a relatively higher probability of influencing postsynaptic target neurons in OB. Biologically, tonic reductions in the level of some odors in the environment would be compensated for by an enhancement in the ability of an animal to detect those odors through changes in dopamine production. Consistent with this suggestion, mitral cell responses in reversible naris occluded rats show enhanced sensitivity to odors (Wilson and Sullivan, 1995). Conversely, in animals chronically exposed to high levels of certain odors, dopaminergic presynaptic inhibition might function to attenuate bulb responsiveness to those, but not other odors.

\section{Conclusions}

The present study provides strong evidence that the transneuronal regulation of $\mathrm{TH}$ in dopaminergic juxtaglomerular $\mathrm{OB}$ neurons is mediated by olfactory nerve synaptic release of glutamate acting on NMDA receptors on those DA neurons. In an in vitro culture model, the expression of $\mathrm{TH}$ in $\mathrm{OB}$ neurons is enhanced by the presence of OE explants. Stimulation of the OB-OE cocultures in vitro by exposure to natural odorants further increases TH expression in OB neurons. This is a direct demonstration that odorant stimulation of ORNs is capable of regulating the expression of $\mathrm{TH}$ in bulb neurons. Increased $\mathrm{TH}$ expression under all conditions is dependent on activation of the NMDA receptors. NMDA receptor antagonists prevent $\mathrm{TH}$ expression normally elicited by coculture with $\mathrm{OE}$ explants and completely block odorant stimulus effects. Furthermore, NMDA receptor agonists directly induce TH. The inability of TTX to block the induction of TH by NMDA stimulation and the immunolocalization of NMDA receptor subunits to these $\mathrm{TH}$ cells in vitro suggests that glutamate acts directly on periglomerular neurons. We hypothesize that the regulation of $\mathrm{TH}$ transcription by glutamate stimulation is the physiologically relevant signal that regulates TH in vivo. 


\section{REFERENCES}

Aroniadou-Anderjaska V, Ennis M, Shipley MT (1997) Glomerular synaptic responses to olfactory nerve input in rat olfactory bulb slices. Neurosci 79:425-434.

Bading H, Ginty DD, Greenburg ME (1993) Regulation of gene expression in hippocampal neurons by distinct calcium signaling pathways. Science 260:181-186.

Baker H (1990) Unilateral neonatal olfactory deprivation alters tyrosine hydroxylase expression but not aromatic amino acid decarboxylase or GABA immunoreactivity. Neuroscience 36:761-771.

Baker H, Kawano T, Margolis FL, Joh TH (1983) Transneuronal regulation of tyrosine hydroxylase expression in olfactory bulb of mouse and rat. J Neurosci 3:69-78.

Baker H, Kawano T, Albert V, Joh TH, Reis DJ, Margolis FL (1984) Olfactory bulb dopamine neurons survive deafferentation-induced loss of tyrosine hydroxylase. Neuroscience 11:605-615.

Baker H, Morel K, Stone DM, Maruniak JA (1993) Adult naris occlusion profoundly reduces tyrosine hydroxylase expression in mouse olfactory bulb. Brain Res 614:109-116.

Ben-Ari Y, Khazipov R, Leinekugel X, Caillard O, Gaiarsa JL (1997) GABAA, NMDA, and AMPA receptors: a developmentally regulated "menage a trois". Trends Neurosci 20:523-529.

Biffo S, DeLucia R, Mulatero B, Margolis F, Fasolo A (1990) Carnosine-, calcitonin gene-related peptide- and tyrosine hydroxylaseimmunoreactivity in the mouse olfactory bulb following peripheral denervation. Brain Res 528:353-357.

Brewer GJ, Torricelli JR, Evege EK, Price PJ (1993) Optimized survival of hippocampal neurons in B27-supplemented Neurobasal, a new serum-free medium combination. J Neurosci Res 35:567-576.

Brosenitsch TA, Salgado-Commissariat D, Kunze DL, Katz DM (1998) L-type calcium channels and neuronal phenotype. A role for L-type calcium channels in developmental expression of transmitter phenotype in primary sensory neurons. J Neurosci 18:1047-1055.

Brunjes PC, Smith-Crafts LK, McCarty R (1985) Unilateral odor deprivation: effects on the development of olfactory bulb catecholamines and behavior. Brain Res 354:1-6.

Carlson GC, Slawecki ML, Lancaster E, Keller A (1997) Distribution and activation of intracellular $\mathrm{Ca}^{2+}$ stores in cultured olfactory bulb neurons. J Neurophysiol 78:2176-2185.

Chen G, Trombley PQ, van den Pol AN (1996) Excitatory actions of GABA in developing rat hypothalamic neurons. J Physiol (Lond) 494:451-464

Cho JY, Min N, Franzen L, Baker H (1996) Rapid down-regulation of tyrosine hydroxylase expression in the olfactory bulb of naris-occluded adult rats. J Comp Neurol 369:264-276.

Cigola E, Volpe BT, Lee JW, Franzen L, Baker H (1998) Tyrosine hydroxylase expression in primary cultures of olfactory bulb: role of L-type calcium channels. J Neurosci 18:7638-7649.

Conn PJ, Pin JP (1997) Pharmacology and functions of metabotropic glutamate receptors. Annu Rev Pharmacol Toxicol 37:205-237.

Coronas V, Srivastava LK, Liang J-J, Jourdan F, Moyse E (1997) Identification and localization of dopamine receptor subtypes in rat olfactory mucosa and bulb: a combined in situ hybridization and ligand binding radioautographic approach. J Chem Neuroanat 12:243-257.

Davis BJ, Macrides F (1983) Tyrosine hydroxylase immunoreactive neurons and fibers in the olfactory system of the hamster. J Comp Neurol 214:427-443.

de Lima AD, Merten MD, Neuritic VT (1997) Differentiation and synaptogenesis in serum-free neuronal cultures of the rat cerebral cortex. J Comp Neurol 382:230-246.

Denis-Donini S (1989) Expression of dopaminergic phenotypes in the mouse olfactory bulb induced by the calcitonin gene-related peptide. Nature 339:701-703.

Du X, Stull ND, Iacovitti L (1994) Novel expression of the tyrosine hydroxylase gene requires both acidic fibroblast growth factor and an activator. J Neurosci 14:7688-7694.

Du X, Stull ND, Iacovitti L (1995) Brain-derived neurotrophic factor works coordinately with partner molecules to initiate tyrosine hydroxylase expression in striatal neurons. Brain Res 680:229-233.

Ennis M, Zimmer LA, Shipley M (1996) Olfactory nerve stimulation activates rat mitral cells via NMDA and non-NMDA receptors in vitro. NeuroReport 7:989-992.

Finger TE, Bottger B (1992) Expression of the dopaminergic phenotype in the olfactory bulb: neither calcitonin gene-related peptide nor olfactory input is necessary. Neurosci Lett 143:15-18.
Frazier LL, Brunjes PC (1988) Unilateral odor deprivation: early postnatal changes in olfactory bulb cell density and number. J Comp Neurol 269:355-370.

Fueshko SM, Wray S (1994) LHRH cells migrate on peripherin fibers in embryonic olfactory explant cultures: an in vitro model for neurophilic neuronal migration. Dev Biol 166:331-348.

Fueshko SM, Key S, Wray S (1998) GABA inhibits migration of luteinizing hormone-releasing hormone neurons in embryonic olfactory explants. J Neurosci 18:2560-2569.

Gong Q, Liu W-L, Srodon M, Foster TD, Shipley MT (1996) Olfactory epithelial organotypic slice cultures: a useful tool for investigating olfactory neural development. Int J Dev Neurosci 14:841-852.

Guthrie KM, Gall CM (1991) Differential expression of mRNAs for the NGF family of neurotrophic factors in the adult rat central olfactory system. J Comp Neurol 313:95-102.

Guyenet PG, Crane JK (1981) Non-dopaminergic nigrostriatal pathway. Brain Res 213:291-305.

Halasz H, Ljungdahl A, Hokfelt T, Johansson O, Goldstein M, Park D, Biberfeld P (1977) Transmitter histochemistry of the rat olfactory bulb. I. Immunohistochemical localization of monoamine synthesizing enzymes. Support for intrabulbar, periglomerular dopamine neurons. Brain Res 126:455-474.

Halasz H, Johansson O, Hokfelt T, Ljungdahl A, Goldstein M (1981) Immunohistochemical identification of two types of dopamine neuron in the rat olfactory bulb as seen by serial sectioning. J Neurocytol $10: 251-259$

Hardingham GE, Chawla S, Johnson CM, Bading H (1997) Distinct functions of nuclear and cytoplasmic calcium in the control of gene expression. Nature 385:260-265.

Hille B (1992) Ionic channels of excitable membranes, Ed 2. Washington, MA: Sinauer.

Isaacs KR, de Erausquin G, Strauss KI, Jacobowitz DM, Hanbauer I (1996) Differential effects of excitatory amino acids on mesencephalic neurons expressing either calretinin or tyrosine hydroxylase in primary cultures. Mol Brain Res 36:114-126.

Johnson JW, Ascher P (1987) Glycine potentiates the NMDA response in cultured mouse brain neurons. Nature 325:529-531.

Keller A, Yagodin S, Aroniadou-Anderjaska V, Zimmer LA, Ennis M, Sheppard Jr NF, Shipley MT (1998) Functional organization of rat olfactory bulb glomeruli revealed by optical imaging. J Neurosci 18:2602-2612.

Kim KS, Lee MK, Caroll J, Joh TH (1993) Both the basal and inducible transcription of the tyrosine hydroxylase gene are dependent upon a cAMP response element. J Biol Chem 268:15689-1569.

Kosaka T, Kosaka K, Hama K, Wu JY, Nagatsu J (1987) Differential effect of functional olfactory deprivation on the GABAergic and catecholaminergic traits in the rat main olfactory bulb. Brain Res 413:197-203.

Koster NL, Norman AB, Richtand NM, Nickell WT, Puche AC, Pixley SK, Shipley MT (1998) Olfactory receptor neurons express D2 dopamine receptors. J Comp Neurol, in press.

Lazaroff M, Patankar S, Yoon SO, Chikaraishi DM (1995) The cyclic AMP response element directs tyrosine hydroxylase expression in catecholaminergic central and peripheral nervous system cell lines from transgenic mice. J Biol Chem 270:21579-21589.

Levitt M, Spector S, Sjoerdsma A, Udenfriend S (1965) Elucidation of the rate-limiting step in norepinephrine biosynthesis in the perfused guinea-pig heart. J Pharmacol Exp Ther 148:1-7.

Lin F, Stevens CF (1994) Both open and closed NMDA receptor channels desensitize. J Neurosci 14:2153-2160.

Maarse H (1991) Volatile compounds in foods and beverages. New York: Marcel Dekker.

Mayer ML, Vyklicky L, Clemonts J (1989) Regulation of NMDA desensitization in mouse hippocampal neurons by glycine. Nature 338:425-427.

Mayer ML, MacDermott AB, Westbrook GL, Smith SJ, Barker JL (1991) Desensitization at NMDA and AMPA-kainate receptors. In: Exitatory amino acids and synaptic transmission (Wheal $\mathrm{H}$, Thompson $\mathrm{A}$, eds), pp 123-140. London: Academic.

McLean JH, Shipley MT (1988) Postmitotic, postmigrational expression of tyrosine hydroxylase in olfactory bulb dopaminergic neurons. J Neurosci 8:3658-3669.

McMillian MK, Mullis SB, Wu GC, Hudson PM, Pennypacker KR, Hong JS (1994) Regulation of tyrosine hydroxylase in olfactory bulb cul- 
tures: selective inhibition of depolarization-induced increase by endogenous opioids. Brain Res 658:105-111.

Miranti CK, Ginty DD Huang G, Chatila T, Greenburg ME (1995) Calcium activates serum response factor-dependent transcription by a Ras- and Elk-1-independent mechanism that involves a $\mathrm{Ca}^{2+}$ calmodulin-dependent kinase. Mol Cell Biol 15:3672-3648.

Nadi NS, Head R, Grillo M, Hempstead J, Grannot-Reisfeld N, Margolis FL (1981) Chemical deafferentation of the olfactory bulb: plasticity of the levels of tyrosine hydroxylase, dopamine, and norepinephrine. Brain Res 213:365-377.

Nagamoto-Combs K, Piech KM, Best JA, Sun B, Tank AW (1997) Tyrosine hydroxylase gene promoter activity is regulated by both cyclic AMP-responsive element and AP1 sites following calcium influx. Evidence for cyclic AMP-responsive element binding protein-independent regulation. J Biol Chem 272:6051-6058.

Nickell WT, Norman AB, Wyatt LM, Shipley MT (1991) Dopamine receptors in the olfactory bulb: possible localization on terminals of the olfactory nerve. NeuroReport 2:9-12.

Pin JP, Duvoisin R (1995) The metabotropic glutamate receptors: structure and functions. Neuropharmacology 34:1-26.

Pixley SK, Pun RY (1990) Cultured rat olfactory neurons are excitable and respond to odors. Dev Brain Res 53:125-130.

Reed R (1998) Opening the window to odor space. Science 279:193.

Ronnett GV, Cho H, Hester LB, Wood SF, Snyder SH (1993) Odorants differentially enhance phosphoinositide turnover and adenylyl cyclase in olfactory receptor neuronal cultures. J Neurosci 13:1751-1758.

Sakagami H, Kondo H (1993) Differential expression of mRNAs encoding gamma and delta subunits of $\mathrm{Ca}^{2+} /$ calmodulin-dependent protein kinase type II (CaM kinase II) in the mature and postnatally developing rat brain. Mol Brain Res 20:51-63.

Sawamura Y, Sakagami H, Kondo H (1996) Localization of mRNA for $\mathrm{Ca}^{2+} /$ calmodulin-dependent protein kinase $\mathrm{I}$ in the brain of developing and mature rats. Brain Res 706:259-266.

Schulman $\mathrm{H}$ (1993) The multifunctional $\mathrm{Ca}^{2+} /$ calmodulin-dependent protein kinases. Curr Opin Cell Biol 5:247-253.

Stone DM, Wessel T, Joh TH, Baker H (1990) Decrease in tyrosine hydroxylase, but not aromatic L-amino acid decarboxylase: messenger
RNA in rat olfactory bulb following neonatal, unilateral odor deprivation. Mol Brain Res 4:291-300.

Stone DM, Grillo M, Margolis FL, Joh TH, Baker H (1991) Differential effect of functional olfactory bulb deafferentation on tyrosine hydroxylase and glutamic acid decarboxylase messenger RNA levels in rodent juxtaglomerular neurons. J Comp Neurol 311:223-233.

Swanson LW, Sawchenko PE, Berod A, Hartman BK, Helle KB, Vanorden DE (1982) An immunohistochemical study of the organization of catecholaminergic cells and terminal fields in the paraventricular and supraoptic nuclei of the hypothalamus. J Comp Neurol 196:271-285.

Trombley PQ, Shepherd GL (1992) Noradrenergic inhibition of synaptic transmission between mitral and granule cells in mammalian olfactory bulb cultures. J Neurosci 12:1985-1991.

Trombley PQ, Westbrook GL (1990) Excitatory synaptic transmission in cultures of rat olfactory bulb. J Neurophysiol 64:598-606.

Trombley PQ, Westbrook GL (1991) Voltage-gated currents in identified rat olfactory receptor neurons. J Neurosci 11:435-444.

Wellis DP, Scott JW (1990) Intracellular responses of identified rat olfactory bulb interactions to electrical and odor stimulation. J Neurosci 64:932-947.

Wilson DA, Sullivan RM (1995) The D2 antagonist spiperone mimics the effects of olfactory deprivation on mitral/tufted cell odor response patterns. J Neurosci 15:5574-5581.

Wu L-G, Saggau P (1997) Presynaptic inhibition of elicited neurotransmitter release. Trends Neurosci 20:204-212.

Xia Z, Dudek H, Miranti CK, Greenberg ME (1996) Calcium influx via the NMDA receptor induces immediate early gene transcription by a MAP kinase/ERK-dependent mechanism. J Neurosci 16:5425-5436.

Yoon SO, Chikaraishi DM (1992) Tissue specific transcription of the rat tyrosine hydroxylase gene requires synergy between an AP-1 motif and an overlapping E-box containing dyad. Neuron 9:55-67.

Zhao H, Ivic L, Otaki JM, Hashimoto M, Mikoshiba K, Firestein S (1998) Functional expression of a mammalian odorant receptor. Science 279:237-242.

Zhou J, Bradford HF, Stern GM (1994) The stimulatory effect of brain derived neurotrophic factor on dopaminergic phenotype expression of embryonic rat cortical neurons in vitro. Dev Brain Res 81:318-324. 